\title{
The Determinants of Cash Conversion Cycle and Firm Performance: An Empirical Research for Borsa Istanbul Turkey
}

\author{
Mesut DOĞAN ${ }^{1}$ \\ Mustafa KEVSER ${ }^{2}$
}

\begin{abstract}
The ultimate goal of firms is to make a profit and to achieve this ultimate goal, firms execute various functions. Finance is one of the basic functions of firms and firms need financial instruments such as cash reserve and outsource to carry out their activities. Cash management within the finance function is an important issue that needs to be carefully considered, especially in the short and medium term financial planning stage. Presently, the high competition among firms forces companies to manage their cash in the most effective way. The conceptual studies on the subject are quite old and date back to Keynes. According to Keynes, firms demand cash for transaction, prudence and speculation. As a result of analysis, it has been determined that cash conversion cycle has an impact on return on assets (ROA) and return on equity (ROE). There is a statistically significant and negative relationship between cash conversion cycle (CCC) return on assets (ROA) and return on equity (ROE). In addition, there is a positive relationship between return on assets (ROA) and firm size while there is a negative and statistically significant relationship between debt ratio $(D E B T)$ and return on assets (ROA).
\end{abstract}

KEYWORDS: cash flow, cash conversion cycle, firm performance, industrial index.

JEL CLASSIFICATION: $L 10, M 21$

\section{INTRODUCTION}

Assets that can be converted into money in a short time of period for continuing company operations are defined as working capital. Working capital is also can be referred to similar definitions. The main purpose of companies is to maximize the firm value. In this context, companies invest on cash values or fix assets according to the sector of the company. Although its share varies in total assets, one of the main fields of the activity of business owners and managers is cash management and cash cycle of enterprises. For this reason, financial managers devote a significant portion of their time to cash management.

One of the first empirical studies on cash conversion cycle was conducted by Chudson in 1945. The ratio of cash and similar items in total assets of companies have increased significantly in the last two decades (Aygün \& İç, 2009). Within this scope, the issue that is emphasized by the academicians is the question of which factors determine the cash needs of enterprises and what are the effects of these factors on business performance.

\footnotetext{
${ }^{1}$ Afyonkocatepe University, Turkey, mesutdogan07@gmail.com (Corresponding author)

2 Bandırma Onyedi Eylul University, Turkey, mustafakevser83@ gmail.com

* This article was presented as a paper at $2^{\text {nd }}$ Bor Conference between 4 and 6 September 2019, İzmir/Turkey.
} 
Cash flows of the enterprises are directly related to the management of cash, inventories, receivables and payables. It is essential to evaluate the idle funds in short term financial instruments, to convert the receivables to cash, to sell the inventories as soon as possible and to pay the debts late without causing cost increases (Çakır, 2013). Cash conversion cycle extends if receivables turnover and inventory turnover periods increase. Cash flow cycle also prolongs if inventories turnover and receivable turnover are constant but debt payments shorten. On the other hand, shortening of the cash flow cycle shows that the times related to inventories turnover and receivable turnover shortened (Ercan \& Ban, 2005).

There are many views on cash determinants and the effects of these determinants on enterprises' financial performance. One of the leading views is that cash assets reduce financial costs. According to this view, increase in the external financing costs and information asymmetry among the enterprises are the determinants of cash conversion cycle (Myers \& Majluf, 1984). But according to Dittmar et al. (2003), this view is not related to the profitability and financing needs of enterprises. Silva (2011) stated Gitman first used cash conversion cycle to measure the impact of working capital management on profitability in 1974. It is also stated that cash conversion cycle could vary by sector (Besley \& Meyer, 2003; Uyar, 2009).

The aim of this study is to determine the relationship between cash flow cycle and firm performance and the factors that determine the cash conversion cycle of the companies operating in Borsa Istanbul (BIST) industrial index. For this purpose, the data of 157 companies operating in BIST industrial index for the period of 2008-2018 were analyzed. In the research, current data were used and 1727 observations were reached in total of 11 years.

Our research consists of six chapters. Following the introduction, the literature review was given in second chapter, in the third chapter the research method was mentioned, the analysis took place in the fourth chapter, discussion is in the fifth chapter and in the sixth chapter, conclusion was presented.

The results of the research are important for the enterprises operating in BIST industry index. In addition, the use of current data in the study increases the importance of our research.

\section{LITERATURE REVIEW}

The literature examining the effects of cash, cash flow cycle and cash flows on business performance is quite extensive.

Researchers (Dittmar et al., 2003) investigated the determinants of cash available for a sample of more than 11.000 firms from 45 countries in the scope of agency theory. According to the results, corporations in countries where shareholder rights are not well protected hold up to twice as much cash as corporations in countries with good shareholder protection.

In addition, Deloof (2003) analyzed the data of 1009 enterprises operating in Belgium in the period of 1992-1996. Regression analyses were used as method in the research. Return on assets, receivable turnover, inventories turnover and accounts payable turnover were the variables of the study. According to the results, receivable turnover, inventories turnover and accounts payable turnover have negative effect on profitability. 
In like manner, İşeri and Chambers (2003) compared the cash conversion cycles of the manufacturing and commercial firms that are operating at the ISE. As a result of the research, it was found that cash conversion cycle is negative in most of the manufacturing firms and in all of the commercial firms.

Özkan and Özkan (2004) investigated the empirical determinants of corporate cash holdings for a sample of United Kingdom firms. In this research, the data of 1092 enterprises for the years 1984-1999 were analyzed with panel data method. According to the results, growth opportunities, cash flows, liquid assets, leverage and bank debt are important in determining cash holdings.

Lazaridis and Tryfonidis (2006) analyzed the data of 131 enterprises for the time of 20012004 operating in Athens Stock Exchange. Regression models were used in the research. Return on assets, receivable turnover, inventories turnover, debt maturity and the leverage were the explanatory variables of the research. According to the results of the research, prolongation of the cash conversion cycle has a negative effect on profitability.

Similarly, Teruel and Solano (2007) examined the effects of working capital management on the profitability of a sample of small and medium sized Spanish firms. For this purpose, the data of 8.872 enterprises for the time of 1996-2002 were analyzed. Regression analyses were used in the research. Return on assets, receivable turnover, inventories turnover, average maturity of debts and leverage were used as variables in the research. According to the results, decreasing of the inventories turnover and receivables turnover has a positive relation with firm value. A negative relation was determined between cash conversion cycle and profitability.

Luo et al. (2009) used the data of the firms operating in Compustat from the industrial, wholesale and retail sectors covering the 1980-2006 period. In the research return on assets (ROA) was used as independent variable. The effects of cash flow cycle, net sales, firm size, assets turnover and profit margin were measured on return on assets (ROA). As a result, it was stated that successful working capital management increases the firm value for shareholders.

Aygün and İç (2009) examined the determinants of cash holdings of the firms in the Turkish Capital Markets. In the research, regression and correlation analyses were applied using the data consisted of 206 companies covering the 2000-2007 period. The results of the research show that working capital, cash flow, firm size, dividend payments, research and development expenditures, growth opportunities and investments were the determinants of the firm cash holdings. In the research no significant relation was found between leverage and cash holding. According to the results, firms with growth opportunities hold two times more cash compared to firms with low growth opportunities.

Nobanee (2009) analyzed the data consisted of 5802 companies covering the period 19902004. In the research dynamic panel data were applied. Operating profit/sales, receivables turnover, inventories turnover, average maturity of debts were the variables of the research. The results of the empirical analysis show that while cash conversion cycle, receivable turnover and inventories turnover have positive effect on profitability, other variables have negative effect. 
Nobanee et al. (2011) investigated the relationship between the firms' cash conversion cycle and profitability. The dynamic panel data analysis was used as the method in the research. Using a sample of 34771 firms covering 1990-2004 period, a strong negative relation between the length of the firms' cash conversion cycle and profitability has been determined.

Coşkun and Kök (2011) investigated the effect of firms' working capital policies on their profitability. The panel data method and GMM estimation technique were used in the research. The data consisted of 74 manufacturing firms listed in Istanbul Stock Exchange covering the 1991-2005 period were analyzed. According to the results, there is a negative relationship between cash conversion cycle accounts receivable period, inventory period and profitability. Also, a positive relationship between profitability and accounts payable period has been determined.

Çakır (2013) investigated the relationship between cash conversion cycle of the enterprises and whether this cash flow cycle has an effect on the profitability of the enterprises. In the research, panel data analyses were applied using the data consisted of 52 companies operating in Istanbul Stock Exchange Industrial Index covering the 2000-2010 period. According to the results, it is determined that the enterprises in manufacturing sector can increase their profitability if they increase the cash flow cycle.

Ege et al. (2016) examined the cash conversion cycle of the companies operating in BIST 50 index. In the research, data of 27 enterprises covering the period 2005-2013 were used and ratio analysis was employed. According to the results, the majority of 27 firms' cash flow cycle is negative, for each year cash flow cycle was calculated positive for 4 firms. In this scope, it can be stated most of the enterprises are successful in cash management and they have sufficient cash levels.

\section{RESEARCH METHOD}

The aim of this study is to analyze the factors determining the cash conversion cycle of the companies operating in Borsa Istanbul (BIST) industrial index and to examine the relationship between the cash conversion cycle and firm performance.

In this research, the data consisted of 157 companies covering the 2008-2018 period were analyzed. In this context, by analyzing the 11 year-data of 157 companies, 1727 observations will be reached.

The variables that affect the cash conversion cycle and have an impact on firm performance are given in Table 1.

The following models have been developed within the framework of the variables shown in Table 1. Models 1 and 2 were developed to measure the impact of cash conversion cycle on firm performance. Model 3 was developed to determine the factors of cash holdings of the firm.

$$
\begin{aligned}
& \text { ROAit }=\beta_{1} \text { CCCit }+\beta_{2} \text { SIZEit }+\beta_{3} \text { DEBTit }+\alpha+\varepsilon_{\text {it }}(\text { Model } 1) \\
& \text { ROEit }=\beta_{1} \text { CCCit }+\beta_{2} \text { SIZEit }+\beta_{3} \text { DEBTit }+\alpha+\varepsilon_{\text {it }}(\text { Model } 2) \\
& \text { CCCit }=\beta_{1} \text { TOBINit }+\beta_{2} \text { SIZEit }+\beta_{3} \text { DEBTit }+ \\
& \beta_{3} \text { DIVIDENDit }+\beta_{3} \text { FIXEDit }+\beta_{3} \text { RDit }+\alpha+\varepsilon_{\text {it }}(\text { Model 3) }
\end{aligned}
$$


Table 1. The variables of the research

\begin{tabular}{|l|l|l|}
\hline \multicolumn{1}{|c|}{ Variables } & \multicolumn{1}{c|}{ Definitions } & \multicolumn{1}{c|}{ Codes } \\
\hline Return on Assets & Net Profit/Total Assets & ROA \\
\hline Return on Equity & Net Profit/Total Equity & ROE \\
\hline Cash Conversion Cycle & $\begin{array}{l}\text { Inventory Holding Period + Receivables Collection Period - } \\
\text { Payables Payment Period }\end{array}$ & CCC \\
\hline Size of Firm & Logarithm of Total Assets & SIZE \\
\hline Debt level & Total Debts/Total Assets & DEBT \\
\hline Tobin's q & Market Value/Book Value & TOBIN \\
\hline Dividend & $100 *$ (Dividend Cash Net / Market Value) & DIVIDEND \\
\hline Investment Expenditures & Purchase of Fixed Assets/Total Assets & FIXED \\
\hline R\&D investments & Research and Development Expenses/ Operating Expenses & RD \\
\hline
\end{tabular}

Source: created by authors

The data used in this study is balanced panel data due to the use of data from manufacturing companies operating in Borsa Istanbul between 2008 and 2018 without interruption. The Stata 11.0 programme was used in the study. We benefited Fisher ADF Unit root tests in our study. In this study, the robust estimator developed by Beck-Katz (1995) was used because it is robust to horizontal section dependence, auto-correlation and heteroscedasticity and can be applied in case of $\mathrm{T}<\mathrm{N}$.

\section{ANALYSIS}

In this chapter of the study, the factors determining the cash holdings of the firms operating in Borsa Istanbul industrial index and the empirical finding regarding the effects of cash holdings on firm performance are given.

Table 2. Descriptive statistics

\begin{tabular}{|l|c|c|c|}
\hline \multicolumn{1}{|c|}{ Variables } & Median & $\begin{array}{c}\text { Standard } \\
\text { Deviation }\end{array}$ & $\begin{array}{c}\text { Number } \\
\text { of observations }\end{array}$ \\
\hline Dividend yield (DIVIDEND) & & & 1727 \\
\hline Cash Conversion Cycle (CCC) & 2.7532 & 3.7432 & 1727 \\
\hline Tobin's q (TOBIN) & 16.443 & 25.254 & 1727 \\
\hline Investment expenditures (FIXED) & 1.835 & 4.123 & 1727 \\
\hline R\&D investments (RD) & .0721 & .1433 & 1727 \\
\hline Debt ratio (DEBT) & .0347 & .0141 & 1727 \\
\hline Total assets (SIZE) & .4432 & .2243 & 1727 \\
\hline Return on assets (ROA) & 20.01 & 1.432 & 1727 \\
\hline Equity on assets (ROE) & .0498 & .0832 & 1727 \\
\hline
\end{tabular}

Source: created by authors

In Table 2, descriptive statistics of dependent and independent variables which were used in the research were given. The average of cash conversion cycle of the manufacturing firms investigated in the research is 16.44. The firms' average of Tobin's Q ratio is 1.83, ROA $4.98 \%$, ROE $9.01 \%$. 
Table 3. Correlation analysis

\begin{tabular}{|l|c|c|c|}
\hline & CCC & ROA & ROE \\
\hline CCC & 1 & -.351 & -.308 \\
\hline DEBT & -234 & -.402 & -427 \\
\hline SIZE & .349 & .210 & .219 \\
\hline FIXED & .318 & .161 & .149 \\
\hline TOBIN & .211 & .371 & .341 \\
\hline DIVIDEND & .394 & .391 & .384 \\
\hline RD & .289 & .216 & .206 \\
\hline
\end{tabular}

Source: created by authors

In the Table 3, the results of the correlation analysis showing the relationship between the cash conversion cycle of firms operating in Borsa Istanbul industrial index and firms' performances are given. As can be seen, there is a positive relationship between cash conversion cycle (CCC) and return on assets (ROA) and return on equity (ROE). In similar, a positive relationship has been determined between cash conversion cycle (CCC) and total assets (SIZE), investment expenditures (FIXED), Tobin's Q, dividend yield (DIVIDEND), research and development investments (RD).

Table 4. The results of robust estimator (Model 1)

\begin{tabular}{|c|c|c|c|c|}
\hline \multicolumn{5}{|c|}{$\begin{array}{l}\text { Dependent Variable: ROA } \\
\text { Years: } 2008-2018 \\
\text { Number of years: } 11 \\
\text { Number of firms observed: } 157 \\
\text { Total number of observation: } 1727\end{array}$} \\
\hline Variables & Efficiency & Std. Deviation & t-statistics & P Value \\
\hline $\mathrm{CCC}$ & -.003242 & .003211 & -2.54 & $0.032^{* * *}$ \\
\hline DEBT & -.004321 & .013421 & -2.89 & $0.001^{* * * *}$ \\
\hline SIZE & .00321 & .023112 & 3.21 & $\mathbf{0 . 0 0 8}^{* * * *}$ \\
\hline Sabit (c) & .02953 & .03741 & 3.43 & 0.000 \\
\hline Constant chi2 & \multicolumn{4}{|c|}{145.43} \\
\hline P Statistic & \multicolumn{4}{|c|}{0.0000} \\
\hline $\mathrm{R}^{2}$ & \multicolumn{4}{|c|}{0.102} \\
\hline
\end{tabular}

In Table 4, the results of robust estimator that show the relationship between cash conversion cycle (CCC) and return on assets (ROA) are presented. In this model, the data consisted of 157 manufacturing firms covering the 2008-2018 period were used in the analyses. As can be seen from the results, heteroscedasticity, inter-unit correlation and autocorrelation were prevented by using Beck-Katz (1995) estimator and in the model, it can be seen that $\mathrm{F}$ statistics level is statistically significant and also the model seems to have sufficient explanatory power. However, approximately $10 \%$ of the change in ROA is explained by the cash conversion cycle. In other words, it is understood that the coefficient of determination $\left(\mathrm{R}^{2}\right)$ used to determine the relative efficiency of the regression model is $10 \%$.

When the results of the model are examined, it is seen that cash conversion cycle (CCC) has an impact on return on assets (ROA) which is the accounting-based performance indicator. There is a negative and statistically significant relationship between cash conversion cycle (CCC) and return on assets (ROA). Also there is a positive relationship between return on 
assets (ROA) and firm size, however there is a statistically significant and negative relationship between debt ratio (DEBT) and return on assets (ROA) $(\mathrm{p}<0,05)$.

Table 5. The results of robust estimator (Model 2)

Dependent Variable: ROE

Years: 2008-2018

Number of years: 11

Number of firms observed: 157

Total number of observation: 1727

\begin{tabular}{|c|c|c|c|c|}
\hline Variables & Efficiency & Std. Deviation & t-statistics & P Value \\
\hline CCC & .00212 & .001994 & 2.41 & $\mathbf{0 . 0 4 1}^{* * *}$ \\
\hline DEBT & -.00328 & .02432 & -2.71 & $\mathbf{0 . 0 0 5}^{* * *}$ \\
\hline SIZE & .00298 & .03052 & 3.05 & $\mathbf{0 . 0 0 9}^{* * *}$ \\
\hline Constant (c) & .03224 & .03103 & 3.22 & 0.000 \\
\hline Wald chi2 & \multicolumn{3}{|c|}{0.000} \\
\hline P Statistic & \multicolumn{4}{|c|}{0.095} \\
\hline $\mathrm{R}^{2}$ & $* * *, * *$ and $*$ show 1\%, 5\% and 10\% the significance level, respectively, Source created by authors
\end{tabular}

In Table 5, the results of robust estimator that show the relationship between cash conversion cycle (CCC) and return on equity (ROE) are presented. When the results of the model are examined, it is seen that cash conversion cycle (CCC) has an impact on return on assets (ROA) which is the accounting based performance indicator. There is a negative and statistically significant relationship between cash conversion cycle (CCC) and return on equity (ROE). Also there is a positive relationship between return on equity (ROE) and firm size, however there is a statistically significant and negative relationship between debt ratio $(\mathrm{DEBT})$ and return on equity (ROE) $(\mathrm{p}<0,05)$.

Table 6. The results of robust estimator (Model 3)

Dependent Variable: CCC

Years: 2008-2018

Number of years: 11

Number of firms observed: 157

Total number of observation: 1727

\begin{tabular}{|c|c|c|c|c|}
\hline Variables & Efficiency & Std. Deviation & t-statistics & P Value \\
\hline TOBIN & .00432 & .08475 & 2.68 & $0.037^{* *}$ \\
\hline FIXED & .00312 & .02632 & 3.76 & $0.000^{* * * *}$ \\
\hline RD & .01380 & .02421 & 3.42 & $0.001^{* * * *}$ \\
\hline DIVIDEND & .00274 & .09345 & 3.55 & $0.000^{* * * *}$ \\
\hline DEBT & -.00143 & .02451 & -4.06 & $0.000^{* * * * *}$ \\
\hline SIZE & .00493 & .02364 & 3.81 & $0.000^{* * * *}$ \\
\hline Constant (c) & .0281 & .03103 & 3.22 & 0.000 \\
\hline Wald chi2 & \multicolumn{4}{|c|}{252.13} \\
\hline P Statistic & \multicolumn{4}{|c|}{0.000} \\
\hline $\mathrm{R}^{2}$ & \multicolumn{4}{|c|}{0.327} \\
\hline
\end{tabular}

In Table 6, the results of robust estimator that determine the factors of cash holdings are presented. When the results of analysis are examined, it is seen that there are positive relationships between cash conversion cycle (CCC) and Tobin's Q ratio, (FIXED), research and development investments (RD), dividend yield (DIVIDEND) and firm size (SIZE). In 
other words, as the market value, investment expenditures, research and development investments and total assets of firms increase also the cash conversion cycle ratio increase as well. However, there is a negative and statistically significant relationship between cash conversion cycle (CCC) and debt ratio (DEBT).

\section{CONCLUSION}

Working capital management has become very important recently. Businesses are particularly careful in managing their receivables, inventories and debts. Cash management which is an important function of working capital has a direct impact on business profitability. In the scope of cash management, the holding of optimum cash reserves of enterprises, compliance of maturities provided to customers with firm profitability, inventory and especially short term debt management play a decisive role on return on assets (ROA) and return on equity (ROE).

The aim of this study was stated as "investigating the determinants of cash conversion cycle and the impact of cash conversion cycles on firm performance". Within this framework, 11 year-data consisted of 157 companies operating in Borsa Istanbul Industrial Index covering the 2008-2018 period were analyzed. In this context, the impacts of receivable turnover, inventories turnover, accounts payable turnover on return on assets (ROA) and return on equity (ROE) were investigated.

As a result of the analysis, it is seen that cash conversion cycle (CCC) has an effect on return on equity (ROE) and return on assets (ROA). There is a negative and statistically significant relationship between return on assets (ROA) and return on equity (ROE). Also, there is a positive relationship between return on assets (ROA) and firm size (SIZE) however there is a negative and statistically significant relationship between debt ratio and return on assets (ROA). There is a positive relationship between cash conversion cycle (CCC) and Tobin's q ratio, investment expenditures (FIXED) research and development investments (RD), dividend yield (DIVIDEND) and firm size (SIZE). When model 1 and model $2 \mathrm{R}^{2}$ values are analyzed, CCC affects approximately $10 \%$ of firm performance. This shows that there are more important factors affecting firm performance. In Model 3, independent variables TOBIN, FIXED, RD, DIVIDEND, DEBT and SIZE explain 32.7\% of the CCC dependent variable.

The results obtained from the research are consistent with Çakır and Küçükkaplan (2012), Deloof (2003), Lazaridis and Tryfonidis (2006). Our empirical findings can contribute to more effective cash management. Sugathadasa (2018) investigated the effect of cash conversion cycle (CCC) on firm performance of firms traded in Sri Lanka Stock Exchange for the period 2003-2017. As a result, it has been determined that cash conversion cycle (CCC) affects the firm performance in Sri Lanka. Anser and Ali Malik (2013) for Pakistani firms, Eljelly (2004) for Saudi Arabian firms, Deloof (2003) for Belgium firms, Zariyawati et al. (2009) for Malaysian firms, Falope and Ajilore (2009) for Nigerian firms, Gill et al. (2010) for U.S. firms, Mohammad (2009) for Iranian firms, Murugesu (2013) for Sri Lanka firms reported the similar results. Unlike the results of this study, Amit et al., (2005) could not determine a statistically significant relationship between cash conversion cycle and firm performance.

Cash conversion cycle is important for each manufacturing firm. Cash conversion cycle helps financial managers to specify the stock holding period. In addition, cash conversion cycle is a 
powerful tool for examining how well the working capital of a manufacturing firm is managed. In order for the company to survive, finance managers need to create a balance between current assets and current liabilities in terms of working management. Financial managers can also manage the cash conversion cycle well to reduce future shortage and bankruptcy risk.

The findings obtained in this study should be evaluated in terms of BIST industrial index. In terms of BIST industrial index firms, shorter period of cash conversion cycle, inventories turnover, receivable turnover indicate that the profitability of manufacturing firms will increase. Industrial firms must accurately estimate and evaluate the entity's cash flows. They accurately identify long-term cash inflows and outflows. They should manage their investment strategies in the abundance of cash correctly and find cost-effective fundings in the time of cash shortages. As a result, due to the changing world economy, technological advances and the increasing global competition among the industrial firms, it is crucial that these companies should increase their effort to optimize the cash conversion cycle for greater profitability.

This research has a number of limitations. Firstly, the findings of the research are based on a study on Borsa Istanbul (BIST). Hence the results cannot be generalized for companies that are not listed on the stock exchange. Secondly, the sample comprises industrial index. Therefore, the results are valid for industrial companies. Thirdly, another limitation of the research is that it covers the period of 2008-2018. In this framework, research can be developed by analyzing different indices or industries, and studies covering a longer period can be carried out. Thus, academic contribution can be increased by obtaining more empirical evidence. The paper is one of the rare studies about the subject conducted in developing countries, and also in Turkey. Therefore, the results obtained from the research are important in terms of developing countries and Turkey.

\section{REFERENCES}

Amit, K. M., Debashish, S., \& Rakshit, D. (2005). Working capital and profitability: A study on their relationship with reference to selected companies in Indian pharmaceutical industry. GITAM Journal of Management, 3, 51-62.

Anser, R., \& Malik, Q.A. (2013). Cash conversion cycle and firms' profitability - A study of listed manufacturing companies of Pakistan. Journal of Business and Management, 8(2), 83-87.

Aygün, M., \& İç, S. (2009). Firma nakit mevcudunun belirleyicileri. Ticaret ve Turizm Ĕ̌gitim Fakültesi Dergisi, 2, 84-102.

Besley, S., \& Meyer, R.L. (1987). An empirical investigation of factors affecting the cash conversion cycle. Presented at the Annual Meeting of the Financial Management Association, Las Vegas, Nevada.

Chudson, W. (1945). The pattern of corporate financial structure. NBER Working Paper Series.

Coşkun, E., \& Kök, D. (2011). Çalışma sermayesi politikalarının karlılık üzerine etkisi: Dinamik panel uygulamas1. Ege Academic Review, Special Edition, 11, 75-85.

Çakır, H.M., \& Küçükkaplan İ. (2012). İşletme sermayesi unsurlarının firma değeri ve karlılığ1 üzerindeki etkisinin İMKB'de işlem gören üretim firmalarında 2000-2009 dönemi için analizi. Muhasebe ve Finansman Dergisi, 53, 69-85. ISSN:2146-3042.

Çakır, H.M. (2013). Nakit döngüsünün firma karlılığı etkisinin sektörel analizi. Journal of Yaşar University, 30(8), 4948-4965.

Dittmar, A., Smith, J.M., \& Servaes, H. (2003). International corporate governance and corporate cash holdings. Journal of Financial and Quantitative Analysis, 38(1), 111-133. 
Deloof, M. (2003). Does working capital management affect profitability of Belgian firms? Journal of Business, Finance and Accounting, 30, 573-587.

Ege, İ., Topaloğlu, E.E., \& Karakozak, Ö. (2016). Nakit dönüşüm süresi analizi: BIST-50 endeksinde yer alan şirketler üzerine ampirik bir uygulama, Niğde Üniversitesi İktisadi ve İdari Bilimler Fakültesi Dergisi, 9(1), 179-193.

Eljelly, A. (2004). Liquidity-Profitability Tradeoff: An empirical Investigation in an Emerging Market. International Journal of Commerce \& Management, 14(2), 48-61.

Ercan, M.K., \& Ban, Ü. (2005). Değere dayalı işletme finansı, finansal yönetim. Ankara, Turkey: Gazi Kitabevi.

Falope, O. I., \& Ajilore, O. T. (2009). Working Capital Management and Corporate Profitability: Evidence from Panel Data Analysis of Selected Quoted Companies in Nigeria. Research Journal of Business Management, 3(3), 73-84.

Gill, A., Biger, N., \& Mathur, N. (2010). The relationship between working capital management and profitability: evidence from the United States. Business and Economics Journal, BEJ-10, 1-9

İşeri, M., \& Chambers, N. (2003). Üretim ve perakende ticaret sektörlerinin nakit dönüşüm süreçlerinin irdelenmesi. Mali Çözüm Dergisi, 62, 1-6.

Lazaridis, I., \& Tryfonidis, D. (2006). Relationship between working capital management and profitability of listed companies in the Athens stock exchange. Journal of Financial Management and Analysis, 19(1), 26-35.

Luo, M.M, Lee, J.J., \& Hwang, Y. (2009). Cash conversion cycle, firm performance and stock value. Retrieved October 01, 2019 from http://www90.homepage.villanova.edu/ michael.pagano/ML_CCC_20090420.pdf.

Mohammadi, M. (2009). The impact of working capital management on profitability of companies in the companies society listed in Tehran Stock Exchange. Journal of Management, pp. 80-91.

Murugesu, T. (2013). Effect of cash conversion cycle on profitability: Listed plantation companies in Sri Lanka. Research Journal of Finance and Accounting, 4(18), 132-137.

Myers, S., \& Majluf, N. (1984). Corporate financing and investment decisions when firms have information that investors do not have. Journal of Financial Economics, 13, 187-221.

Nobanee, H. (2009). Working capital management and firm's profitability: An optimal cash conversion cycle. Retrieved October 01, 2019 from https://papers.ssrn.com/sol3/ papers.cfm?abstract_id=1471230.

Nobanee, H., Abdullatif, M., \& Al Hajjar, M. (2011). Cash conversion cycle and firm's performance of Japanese firms. Asian Review of Accounting, 19(2), 147-156.

Özkan, A. \& Özkan, N. (2004). Corporate cash holdings: An empirical investigation of UK companies. Journal of Banking \& Finance, 28, 2103-2134.

Silva, F. (2011). Effects of working capital management on the profitability of Portuguese manufacturing firms, Universidade do Minho, Master Thesis.

Sugathadasa, D. D. K. (2018). The relationship between cash conversion cycle and firm profitability: special reference to manufacturing companies in Colombo stock Exchange. IOSR Journal of Economics and Finance, 9(6), 38-47.

Teruel, P.J.G., \& Solano, P.M. (2007). Effects of working capital management on SME profitability. International Journal of Managerial Finance, 3, 164-177.

Uyar, A. (2009). The relationship of cash conversion cycle with firm size and profitability: An empirical investigation in Turkey. International Research Journal of Finance and Economics, 24,186-193.

Zariyawati, M. A., Annuar, M. N., Taufiq, H., \& Abdul Rahim, A. S. (2009). Working capital management and corporate performance: case of Malaysia. Journal of Modern Accounting and Auditing, 5(11), 47-54. 